\section{Baseny i kąpieliska geotermalne w Islandii jako element przestrzeni publicznej. Rozwiązania funkcjonalne, przestrzenne i krajobrazowe sprzyjające kontaktom społecznym}

Swimming pools and geothermal baths in Iceland as an element of public space. Functional, spatial and landscape solutions conducive to social contacts

Streszczenie

Baseny kapielowe i pływackie są powszechnym elementem infrastruktury społecznej wielu miejscowości w Islandii. Pełnią nie tylko funkcję rekreacyjną i sportowa. Dzięki swojej powszechności, niskiemu kosztowi dostępu, a także atrakcyjnośc gorących kapieli w chłodnym klimacie, otwarte publiczne baseny sa rodzajem specyficznych dla Islandii przestrzeni publicz nych. Rekompe.
nej strukturze. nej strukturze.
Wykorzystując narzędzia wielokrotnych studiów przypadków, z zastosowaniem technik analizy literatury i rysunku architek-
tonicznego, wizyt w terenie i obserwacii nieuczestniczacej, analizie poddano rozwiazania architektoniczne i krajobrazowe zastosowane $w$ trzech realizacjach otwartych basenów $i$ kąpielisk $w$ Islandii pod kątem przypisywanej im funkcji publicznej, integrującej i społecznej.

W wyniku przeprowadzonej analizy ustalono że: nieczęsto program użytkowy basenu bywa uzupełniany funkcjami towarzyszacymi, takimi jak np. kawiarnia; rozwiazzania projektowe kạpielisk obejmują niecki i jacuzzi z gorącą wodą o różnej wielkości, kształtach i zorientowaniu względem obiektu; wspólną cechą analizowanych obiektów jest powiązanie widokowe kạpieliska i niecek z gorącymi źródłami z krajobrazem.

\section{Abstract}

Bathing and swimming pools are a common element of social infrastructure of many of Iceland's localities. Their function is not limited to recreation and sports. Thanks to their spread, low admission costs, as well as the attractiveness of hot baths in
the cold climate, open public pools are a type of public spaces that are specific to Iceland. They compensate for the lack of traditionally understood urban spaces in localities and settlements that feature a dispersed structure of low density.

Using tools such as the multiple-case study with the application of the techniques of analysing literature and architectura drawings, on-site visits and non-participatory observation, the author analysed the architectural and landscape solutions applied in three built projects featuring open-air pools and bathing facilities in Iceland in terms of their ascribed public, integrating and social function.

As a result of the analysis, the author determined that: the functional programme of the pool is not commonly supplemented by accompanying functions, such as, for instance, coffee shops; the design solutions of the bathing facilities include pools lysed structures was the visual connection of the bathing facilities and the hot tubs with the landscape.

Stowa kluczowe: baseny geotermalne, energia geotermalna, infinity pool, krajobraz, przestrzeń publiczna, Islandia ołożona - na połnocnym Atlantyku Islandię dzieli od wybrzeży Szkocji prawie 800, a od Norwegii blisko tysiąc kilometrów. Nic więc dziwnego, że Islandia była ostatnim krajem europejskim, który został trwale zasiedlony'. Stali osadnicy przybyli na wyspe około 870 roku z Norwegii. Górzysty i wyżynny krajobraz wyspy, którego jedna czwarta powierzchni zajmuja lodowce lawa i piaski, a ponad połowe nieużytki, nie oferowa dogodnych warunków do zamieszkiwani Poza orowa uksztattowaniem terenu oraz chtodnym klimatem, osadicy musieli mierzyć sie z konsekwencjami szczególnej budowy geologiczej. Przez wyse prabiega bowiem budowy geologicznej. Przez wyspę przebiega bowiem Gra pót srodar ną póno no jest powska od eurazjatyckiej. Polożenie na styku plyt jest powodem obsenwowanej aktywnosci wulkanicznej oraz licznych zjawisk geotermalnych. Wskutek niesprzyjającego Klimatu, niewielkiej powierzchni gruntow ornych ${ }^{3}$, braku surowców mineralnych, wielowiekowej zaležnosci od Norwegii i Danii i związane $z$ tym gospodarczej izolacji oraz konsekwencji aktywności wulkanicznej Islandia była jednym z najbiedniejszych obszarów w Europie. Populacja wyspy była wielokrotnie dziesiątkowana w wyniku chorób, głodu i klęsk żywiolowych $i$ az do lat 20. XIX wieku nie przekraczala 50 tys. mieszkańców ${ }^{4}$. Z powodu biedy na przełomie XIX i XX wieku blisko $20 \%$ populacji opuściło wyspę, emigrując do Ameryki Północnej, głównie do Kanady.

Strategiczne położenie na północnym Atlantyku oraz wkroczenie wojsk niemieckich do Danii, z którą Islandia była od 1918 roku połączona unią personalną, było przyczyną prewencyjnego zajęcia wyspy w 1940 roku przez armię brytyjską. Rok później ulokowano na niej amerykańska baze wojskowa. Liczba amerykańskich żołnierzy stacjonujacych na wyspie w trakcie wojny siegneła 40 ysiecy wobec 120 tysiecy mieszkańców. Amerykańska baza działała na wyspie do 2006 roku.

W 1944 Islandia ogtosita niepodlegtość. Po wojnie kraj Wostał czloliom ckiego (NATO) oraz przystapit do Planu Mars

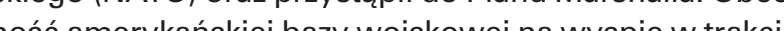
nosc a

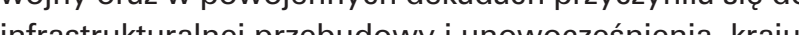
infrastrukn a pej przebuchy iunowoczesnienia kraju, a także byla impulsem do rozwoju gospodarczego, ktory nabral znacznego przyspieszenia po ll wojnie swatowej. Glówną gałęzią gospodarki stało się rybołówstwo i przetwórstwo żywnosci. Równiez po II wojnie światowe zaawansowaniu ulegly prace nad wykorzystaniem na szeroką skalę wyjątkowego atutu wyspy jakim są zasoby energii odnawialnej - energii rzek i geotermalnej. Dostępność taniej energii elektrycznej umożliwiła rozwó wysoko energochłonnego hutnictwa aluminium, które obecne jest na wyspie od 1969 roku.

W 2008 roku gospodarka Islandii znacznie ucierpiała w wyniku swiatowego kryzysu gospodarczego. Wywołane nim znaczne osłabienie islandzkiej waluty dało z kolei początek boomowi turystycznemu, ktorego Islan-
Introduction

celand, which is located in the North Atlantic Ocean, is separated from Scolland's shores by a distance of almost $800 \mathrm{~km}$, while from those of Norway - by close to a thousand. It is no wonder then, that Iceland was the last European country to feature permanent settlement'. Permanent settlers came to the island around 870 from Norway. The mountainous and highland-like landscape of the island, a quarter of which is occupied by glaciers, lava and sand, with the remaining half taken up by wasteland, did not offer comfortable conditions for settlement. Apart from had to face the consin and the cold climate, settlers had to face the consequences of its distinct geologiRidge, which separtes the North American tectonic ing from the Eurasian one. It location at the point of contact between the plates is the reason for its observed volcanic activity22, as well as numerous geothermal phenomena.

Due to the unfriendly climate, the small amount of farmland ${ }^{3}$, the lack of mineral resources and many centuries of dependence on Norway and Denmark as well as the associated economic isolation and the consequences of volcanic activity, Iceland was one of the poorest areas of Europe. The population of the sland was decimated numerous times by disease, famine and natural disasters and up until 1820 its population did not exceed 50 thousand inhabitants ${ }^{4}$ Due to poverty, close to $20 \%$ of the population left the island at the turn of the nineteenth and twentieth century, emigrating to North America, primarily to Canada.

Its strategic location on the North Atlantic and the German invasion of Denmark, with which Iceland was bound by a personal union since 1918, led to the preventive occupation of the island in 1940 by the British army. An American military base was established there a year later. The number of Amercan troops stationed on the island during the war reached 40 thousand, while the number of inhabitants was 120 thousand. The American military base operated on the island until 2006.

warth war the country became one of the founding memwar an American miltery base on the island during the war and in the post-war decades led to an infastructural redevelopment and modernisation of the country in addition to constituting an impulse for economic growth which accelerated significantly af ter the Second World War. Fishing and food processing became the main branch of the economy. Work on making wide-scale use of the island's exceptiona advantage in the form of renewable energy sources - hydroelectric and geothermal power - advanced after the Second World War as well. Access to cheap electric power made it possible to develop energyintensive aluminium smelting plants, which have been present on the island since 1969 
dia doświadcza do dziś. Od 2011 roku coroczny wzrost jest dwucyfrowy (w 2016 roku wzrost o 39\% w stosunk do 2015 roku) 5 . W 2017 liczba zagranicznych odwiedzających przekroczyła 6,5 raza liczbę mieszkańców wyspyOd 2013 roku turystyka jest główną gałęzią gospodarki wyprzedzając dotychczas wiodace rybołówstwo i przetwórstwo ryb oraz hutnictwo aluminium.

\section{Energia odnawialna}

W Islandii, charakteryzującej się niezbyt sprzyjającym klimatem zapotrzebowanie na energię do ogrzewania jest większe niż $w$ większości innych krajów. Wobec niedostatku drewna ${ }^{6}$, głównym źródłem energii do celów bytowych (ogrzewania pomieszczeń i gotowania) aż do XIX wieku były torf oraz suszone glony morskie ${ }^{7}$ a $w$ terenach wiejskich odchody owiec 8 . Około 1870 roku zaczęto do celów bytowych wykorzystywać importowany węgiel. Stał się on powszechny na początku XX wieku i pozostał głównym paliwem do ogrzewania do końca II wojny światowej. Po I wojnie światowej zaczą upowszechniać się olej opałowy, z którego na początk lat 50. XX wieku korzystało $20 \%$ gospodarstw. W tym czasie $40 \%$ gospodarstw wciąż było ogrzewanych węglem, natomiast już $25 \%$ z nich ogrzewano energia ze źródeł geotermalnych. W połowie lat 60 . XX wiek całkowicie zaprzestano ogrzewania węglem, wzrós natomiast znacząco udział oleju opałowego, który jednak zaczął maleć w latach 70. na skutek drastycznego wzrostu cen tego surowca, spowodowanego kryzysem naftowym.

Współcześnie, dzięki opracowaniu i wdrożeniu stosownych technologii Islandia jest pionierem $\mathrm{i}$ liderem w wykorzystaniu energii geotermalnej bezpośrednio do ogrzewania pomieszczeń. Według danych z 2013 roku w ten sposób wykorzystywane jest $43 \%$ zagospodarowane energii geotermatne. Whod weoter

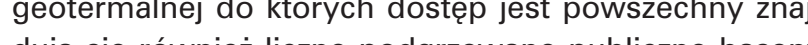

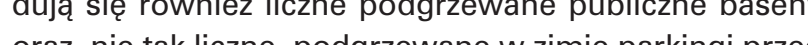
oraz, nie tak licz lic, podgrzewane w zimie pankingi przed pulic, glownie w Rejiculuz. Energia gedermana jest row glownie w Rejkawh. Energia geotermala jest również wykorzystywana do wytwarzania prądu oraz, n

Dzięki opracowaniu i wdrożeniu technologii wykorzy stania unikalnych zasobów naturalnych - energii rzek oraz energii geotermalnej - w II połowie XX wieku Is landia przeksztalcila się z jednego z najbiedniejszych regionów Europy w kraj o wysokim poziomie życia, gdzie niemal $100 \%$ en wil wy zyskuje się ze źródeł odnawialnych. Warto podkreślić, ze szczególnie zasoby energii geotermalnej są eksploatowane w taki sposób, by korzyści z niej wynikające docierały do całego społeczenstwa. Pola zastosowan energii geotermalnej ilustrują wpływ technologii na życie Islandczyków, w tym na istotny wzrost komfortu życia codziennego.
In 2008 Iceland's economy greatly suffered due to the turn, gave rise to a boom in tourism, which lceland is enjoying to this day. Since 2011 the yearly increas in the number of foreign tourists visiting Iceland has been in the double digits (in 2016 it increased by 39\% in relation to 2015)5. In 2017 the number of foreig tourists visiting the country exceeded the number of its inhabitants 6,5 times. Since 2013 tourism has been the primary branch of the economy, moving ahead of
the previously dominant fishing, fish processing and aluminium smelting sectors.

\section{Renewable energy}

cterised by a rather unfriend in the energy need for heating is greater than timber $^{6}$ the main (space heating and food preparation) until the nineteenth century was turf and dried seaweed ${ }^{7}$, while in rural areas sheep droppings were used ${ }^{8}$. Imported coal started to be used for domestic purposes around 1870. It became widespread at the start of the twentieth century and remained the primary heating fue until the end of the Second World War. After the First World War oil started to become common and was used by $20 \%$ of households at the start of the 1950 's. At that time, $40 \%$ of households were heated by coal while as much as $25 \%$ used geothermal sources for heating. During the middle of the 1960's coal-based heating was completely phased out, while the share of oil fuel rose significantly, although it began to drop in the 1970's as a result of the sharp increase in the price, which had been caused by the oil crisis. Currently, thanks to the development and implementation of appropriate technologies, Iceland is a pioneer and leader in the use of geothermal energy for space heating. According to data from 2013, 43\% of its geothermal energy was used in this manner ${ }^{\circ}$ Among the uses of geothermal energy, to which ac cess is common, there are also numerous heated public pools and, although not as numerous, parking lots in front of public institutions that are heated in the winter and selected pavements along streets, also used to produris er scale, in agriculture and industry.

Thanks to the devepment and application of technoogy using unique natura resources - the energy of iv ers and geothermal energy - in the second half of the twentieth century, lceland transformed from one of the poorest regions of Europe into a country with a high standard of living, where almost $100 \%$ of stath a high ergy is drawn from renewable sources. It should also be highlighted that, specifically, geothermal energy sources are used in such a manner so that the benefits derived from it reach the entire society. The fields of the use of geothermal energy illustrate the positive impact of technology on Icelanders' lives, including an essential increase in the comfort of everyday life.
Baseny geotermalne i gorące żródła

u zastosowanie energii geotermalnej $w$ Islandii było ograniczone do kapieli, prania i gotowania, wyłącznie w miejscach gdzie wysteepowały ciepłe i gorące źródła. Dzięki opracowaniu i wdrożeniu technologii wykorzystania i przesyłu energii geotermalnej, korzyści z tego unikalnego zasobu środowiska sa obecnie szeroko udostepniane spoteczeństwu m. in. w basenach. W Islandii znajduje sie ponad 160 rekrea cyjnych basenów pływackich i kapielowych. Wiekrszóc

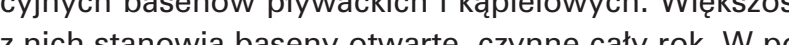
2 nich stan 130 nia basen or wo i gia geotermalna ${ }^{10}$. Podgrzewnie wody w kapieliskach go ghani w skali kraju $4 \%$ zagospodarowan pochania w skel praju 4\% zagospodarowanej energi i producii pradu, obszarem jej wykorystani Istreja i produkcji prąadu, obszarem jej wykorzystania. Istnieja rojduje sie ciepla woda pobiera w wrost z uecia geoznajduje się ciepła woda pobierana wprost $z$ ujęcia geo termalnego, jednak są one nieliczne.

Baseny i kąpieliska pelnia w Islandii nie tylko funkcję re kreacyjną oraz sportową. Uważa się, że stały się one charakterystycznym dla wyspy rodzajem przestrzeni publicznej i miejscem spolecznej integracji". Ta ich rola wynik nie tylko $z$ dobrej dostępności basenów z podgrzewan wodą (jeden basen przypada na 2000 mieszkańców kraju i praktycznie znajduje się w niemal każej miejscowości) ale również z popularności i rangi jakiej nadano pływani $w$ pierwszej połowie XX wieku, w okresie formowania sie współczesnej, niepodległej Islandii'12. Od lat 40. XX wieku lekcje pływania są obowiązkowe dla wszystkich uczniów szkół podstawowych w wieku 6-13 lat, co motywowan było i jest względami bezpieczeństwa i zdrowotnymi. Współcześnie powszechnej nauce pływania przypisuje się też pozytywny wpływ na ksztaltowanie odpowiedzialnego zachowania i na rozwój poznawczy dzieci i młodzie ży oraz na rozwijanie wśród nich umiejetności spotecznych, $w$ tym szacunku do innych ludzi ${ }^{3}$.

$W$ latach 60. XX wieku charaker wizyt na basenach

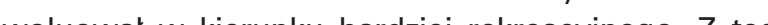
powodu program uzy kómy wieszosi kạpilisk obej-

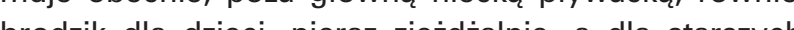

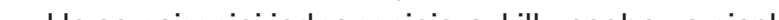
wh ke co najmiej jedną miejsza, kilk a osobową niecke u jacuzi do relaksuz wo da o wyzzzejtempenat udogodnienia sprawily, ze w ostatnich dekadach baseny stały się popularnym sposobem spędzania wolnego czasu oraz chęnie wybieranym miejscem spotkan duże części islandzkiego społeczeństwa, niezależnie od wie ku. Wspołczesna kultura kąpieli w otwartych basenach oraz relaksu w wannach z gorącą wodą jest specyficznym dla Islandii fenomenem, z ustalonym kodem zachowan, przyjętym i szeroko akceptowanym. W tym sensie, baseny pefnią funkcję szeroko dostępnych centrów spolecznosci, po części rekompensujących brak dynamicznego życia miejskiego w generalnie rozproszone zabudowie islandzkich osad i wyspy w ogóle $e^{14}$. Gorąca woda wynagradza mankamenty chłodnego klimatu wy-
Geothermal pools and hot springs

Up to the beginning of the twentieth century the use of geothermal energy in Iceland was limited to bathing, washing and cooking and only in areas where warm and hot springs were present. Thanks to the development and application of technology of the use and transfer of geothermal energy, the benefits of this unique environmental resource are currently widely accessible to society at, among other places, swimming and bathing pools. In Iceland there are over 160 recreational swimming and bathing pools. Most of them are open-air pools, open throughout the entire year. In over 130 of them the water in the pools is heated with geothermal energy ${ }^{10}$. Heating the water of bathing facilities consumes $4 \%$ of the feld of its use, right after space heating and the pro-

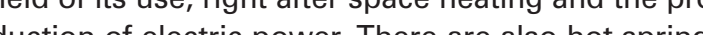
and bating facilities in which the pools ar filled with warm water taken straight from a geotherma spring, although these are not as common.

In Iceland, the function of pools and bathing facilities is not limited to recreation and sports-related functions. It is believed that they have become a form of public space and a place of social integration distinct of the island ${ }^{11}$. Their role in this capacity has been the result of not only good accessibility to pools with heated water (there is one pool per every 2000 residents of the country and one is located in practically every locality), but also the popularity and rank that swimming began to enjoy in the first half of the twentieth centry, during the formation of contemporary, independent Iceland ${ }^{12}$. Since the 1940's swimmin lessons have been mandatory for all students of primary schools aged 6 to 13 , which has been motivated by safety and health-related reasons. Currently the widespread teaching of swimming is being ascribed with a positive influence on the shaping of appropriate behaviour and the cognitive development of children and adolescents, as well as the development of their social skills, including respect for others

In the 1960 's the character of visits to swimming pools evolved in the direction of a more recreational one. For his reason the functional programme of the majority of bathing facilities currently features, apart from a main swimming pool, also a smaller tub for least on additional smeller, severat as well as at Jacuzzi for relaxation, with water at a higher temperature for older visitors. The con a higher temcaused pools to become a popular form of spending free time in recent decades, as well as a commonly chosen place for meetings of a large portio of Icelandic society, regardless of age. The contemporary culture of bathing in open pools and relaxing in hot tubs is a phenomenon that is specific to Iceland, with an established code of behaviour, one that is widely adopted and respected. In this sense swimming pools play the role of generally accessible community centres, partially compensating for the lack of dynamic city life in the generally dispersed 


\section{Dyskusja}

Obiekt w Hofsós jest jednym z najnowszych i najatrakcyjniejszych pod względem architektonicznym basenów w Islandii. Rozwiązania architektoniczne sa nie tylko funkcjonalne, ale również efektowne i stosowne. Wartość realizacji jest tym większa, że idea projektowa basenu rozwija walory kulturowe i krajobrazowe miejsca. Wzajemna relacja zróżnicowanego terenu, wpisa nego weń podłużnego budynku oraz osłonietego od nego wh portego ga krajobraz plateau z niecko od nowa stuży wyekponowaniu i skadrowa i wid basewowy fiordu z sylwetka wyspy Drangey na horyzon na Wstepp na kąpielisk cie brak programu towarzyszacego: barku, kawiarni czy nawet automatuz napojami Spoleczny wy miar przestrzeni realizuje się przede wszystkim w Klikunastoosobowe niecce z gorącą woda, w Ktorej stall bywalcy i przypadkowi goście, wchodzą w lužne kontakty o niskiej intensywności. Niezwyka sceneria, w jakiej osadzony jest obiek o wysokich walorach architektonicznych jest oprawą dl tak rozumianej istoty miejskości.

\section{Krossneslaug}

Otwarty geotermalny basen Krossneslaug w Krossnes położony jest W odludnej części Fiordów Zachodnich, w połnnocno-zachodniej częsci wyspy. Najbliższa większa miejscowość (liczący około 400 mieszkańców Hólmavík) jest odległa o ponad dwie godziny jazdy szutrową drogą wijącą się wzdłuż wybrzeża, opadającego stromo do oceanu. Populacja całej gminy, w które leży Krossnes wynosi zaledwie 43 mieszkańców ${ }^{18}$. Otwarty w 1954 roku obiekt obejmuje nieckę basenowa o wymiarach 12,5 na 6 metrów, jacuzzi oraz przyległy prosty, niewielki, szalowany deskami budynek miesz czacy przebieralnie i sanitariaty. Inaczej niz w Hofsós, niecka basenowa nie jest zagłebiona w terenie, also posadowiona wprost na kamienistej plaży Norðurjeörysadowion do basenu jest możliwy z dwóch stron - od Dosteny do basenu jest mozluy z dwóch ston -od - natomiast $z$ dwóch pozostałych stron basen otwiera

\section{Discussion} attractive pools in lceland in terms of architecture. The architectural solutions are not only functional, but also impressive and proper. The value of the project is the design developed the cultural and landscape qualties of the area. The mutual relationship of the varied the plateau with the swimming pool, is meant to ex pose and frame the view of the waters of the fjord with he outline of Drangey island on the horizon.

There is a small admission fee for using the facility. The structure does not feature an accompanying programme: a small bar, coffee shop, or even a vendreacher primaly in the hot tub for around a dozen people, in which usual customers and random guests enter loose, low-intensity social contact. The extraordinary scenery in which the structure is placed, with high architectural qualities, is a framework for this understanding of the essence of urbanity.

\section{Krossneslaug}

The outdoor geothermal Krossneslaug pool in Krossnes is located in the sparsely populated part of the land. The closest town (Hólmavik, with around 400 residents) is located at a distance of two hours' worth coast that drops steeply into the ocean. The population of the entire community of which Krossnes is a part of is only 43 inhabitants ${ }^{18}$. The facility, opened in 1954, includes a swimming pool that is 12,5 by 6 metres, a Jacuzzi and a small, adjacent building clad intimber boards which houses changing rooms an directly on the recky Norðurfï̈rður bead located to the pool is avalable from two sides - from land and from the side of the building with the changing rooms - while on the two remaining sides the pool
The structure in Hofsós is one of the latest and most even greater due to the fact that the concept behin terrain, the elongated building blended into it and of Western Fjords, in the north-western part of the isof driving along a gravel road which winds along the toilets. Differently than in Hofsos, the swimming poo

II. 3. Widok ogólny niecki i budynku basenu Krossneslaug. Niecka basenowa jest posadowiona wprost na kamienistej plaży. Fot. siggi mus na
licencii CC BY-NC-SA 2.0 III. 3. General view of the pools and building of the Krossneslaug swimming pool. The swimming pool rests directly on the rocky beach. Phot. by
siggi mus, fair use based on CC BY-NC 2.0 license II. 4. Widok $z$ basenu Kross
z przeszkleniami. Fot. autor III. 4 . View from the Krossneslaug pool in the direction of the ocean. To the left one can see a fragment of the Jacuzzi tub sheltered from the wind
by a timber screen with glazing. Original photograph
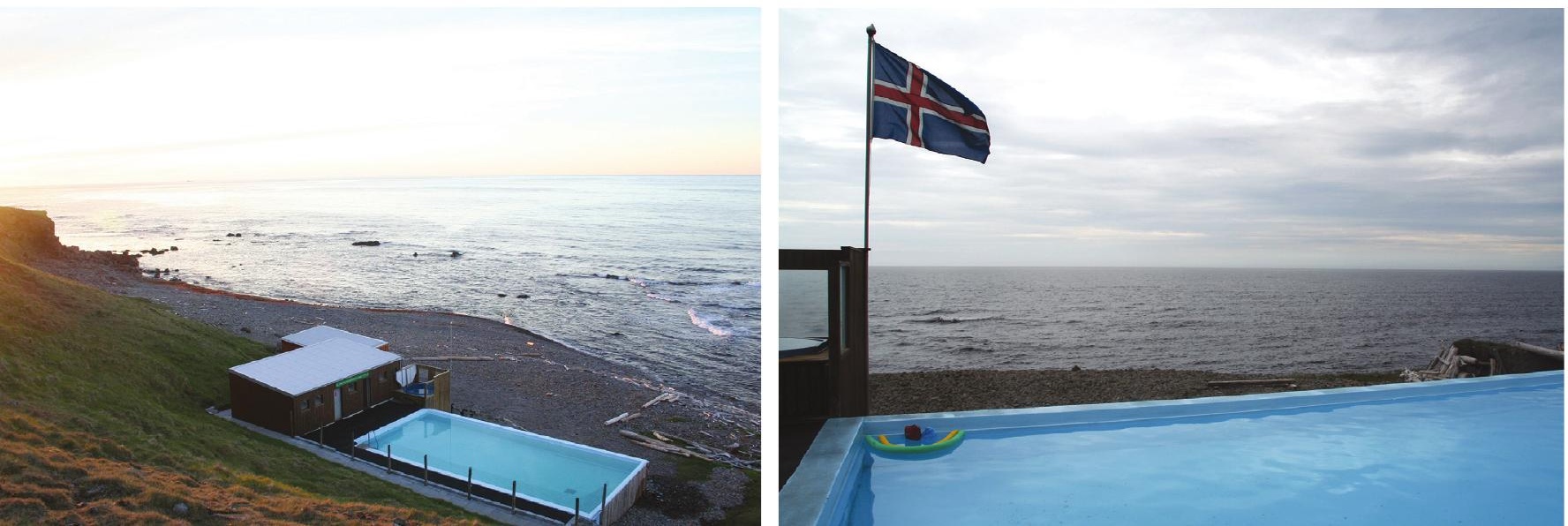

się w kierunku oceanu. Niecka basenu nie ma krawędzi przelewowej, natomiast betonowe obrzeże wyprowadzone jest ze wszystkich stron około $30 \mathrm{~cm}$ powyżej poziomu lustra wody. Dzięki wysokiej przejrzystości wody $w$ basenie oraz pomalowaniu jasnobłękitną farbą nie tylko bocznych, ale i górnych płaszczyzn niecki, w wybranych ujęciach ma się wrażenie zanikania krawedz basenu, a wiẹc efektu podobnego, co w opisanym wcześniej basenie w Hofsós. W Krossnes jednak osiagnieto to za pomoca znacznie prostszego i techniczne ie nały, niemniej satysfakcjonujący.

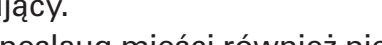
Oprócz glowe

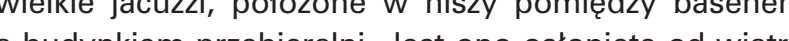
a budynkiem przebieralni. Jest ono oslonięte od watru drewnianymi parawanami z przeszkleniami. Jacuzzi jest tak zorientowane względem reszty obieku, ze korzystaący z niego zwróceni są twarzami do siebie, natomias tyłem do widoku na ocean.

Dyskusja

Podobnie jak w Hofsos, kąpielisku w Krossnes nie towarzyszy żaden program uzupełniający, a wstęp na kąpielisko wiąże się z niewielką opłatą. Rozwiązania architektoniczne są niezwykle proste i podporządkowan przede wszystkim wymogom funkcjonalnym. $O$ atrakcyjności basenu w Krossnes przesądza położenie na brzegu oceanu i otwarcie widokowe w jego kierunk oraz daleka od doskonałości, niemniej udana i efektowna próba wizualnego scalenia wód basenu i oceanu. Dla mieszkańców gminy czynny cały rok basen jest jedną z niewielu atrakcji i przestrzeni publicznych w pobliżu. Turystów może pociągać położenie basen w niezwykłej scenerii, w odległej i najmniej zaludnion części Islandi.

\section{Mývatn Nature Baths}

Położone w północnej części wyspy okolice jeziora Mývatn są obszarem intensywnej aktywności wulkanicznej i występowania zjawisk geotermalnych. Turystów przyciągają w ten rejon liczne atrakcje przyrodnicze, m.in. krater Hverfjall (pozostałość po erupcji wulkanu sprzed 2700 lat), czynny wulkan Krafla, efektowne formacje lawowe $w$ tym jaskinie, a także pole geotermalne Hverir, na którym można obserwować widowiskowe ekshalacje wulkaniczne wytrącające na powierzchni żó te związki siarki. Samo jezioro jest środowiskiem życia ponad 115 gatunków ptaków, w tym blisko 30 gatunków kaczek. Jezioro Mývatn i otaczające je mokradła są objęte ochroną jako rezerwat przyrody.

Otwarte w sąsiedztwie jeziora w 2004 roku kąpielisko Mývatn Nature Baths jest drugim, po otwartej pięć lat wcześniej Błękitnej Lagunie, największym i najpopularniejszym dużym kompleksem kapielowym w Islandii'19. Zarówno Błękitna Laguna (ang. Blue Lagoon) jak i Mývatn Nature Baths są uksztaltowanymi przez człowieka dużymi, sztucznymi zbiornikami wodnymi w na- a catching pool, instead featuring a concrete sill that ises around $30 \mathrm{~cm}$ above the water level on each side. Thanks to the high clarity of the water and the painting of not only the sides, but also the upper surfaces of the pool in a light blue colour, in selected views one can get the impression that the edges of the pool simply disappear, which is a similar effect to the one previously described in the pool in Hofsós. In Krossnes, however, it was achieved with a much simpler and technically unrefined solution, and while the effect is not perfect, it is nevertheless satisfying. Apart from the main pool, Krossneslaug also features a small Jacuzzi, located in the recess between the swimming pool and the building with the changing rooms. I is shielded from the wind by wooden screens a way relative to the remaining part of the facility that hose who use it are turned so that they face each other, while facing away from the view of the ocean.

\section{Discussion}

Similarly as in Hofsós, the bathing facility in Krossnes is not accompanied by any sort of supplementary programme and the facility can be accessed after tions are extraordinarily simple and are primarily subjected to functional requirements. The attractiveness of the swimming pool in Krossnes is determined by its location on the ocean shore and the visual opening towards it, as well as by the far from perfect, yet nevertheless successful and impressive attempt at visually connecting the water of the pool with that of the ocean. To the residents of the community, the swimming pool that is open throughout the entire year is one of the few attractions and public spaces nearby. Tourists can be attracted by the location of the pool in the extraordinary scenery, in the distant and least-populated part of Iceland.

\section{Mývatn Nature Baths}

Located in the northern part of the island, the vicinity of Lake Mývatn is an area of intense volcanic activity and the occurrence of geothermal phenomena. Tour ists are attracted to this region by the numerous natural attractions, e.g. Hverfjall crater (which is a remnant of a volcanic eruption from 2700 years ago), the accluding aves, as well as the Hverir geothermal fien on which one as well as the Huerir geothermal ield, ations that cause yelow suphuric compounds to be deposited on the yurface The lake itself is a habitat for over 115 bird species including close to 30 species of ducks. Lake Mivatn and the surrounding marshes are under protection as a natural preserve.

The Mývatn Nature Baths pool complex that was opened in the area of the lake in 2004 is the secondlargest and most popular large bathing facility in Iceland after the Blue Lagoon, which was opened five years prior $^{19}$. Both the Blue Lagoon and Mývatn Nature Baths are man-made, large, artificial pools of water located in a natural scenery, which serve primar- 


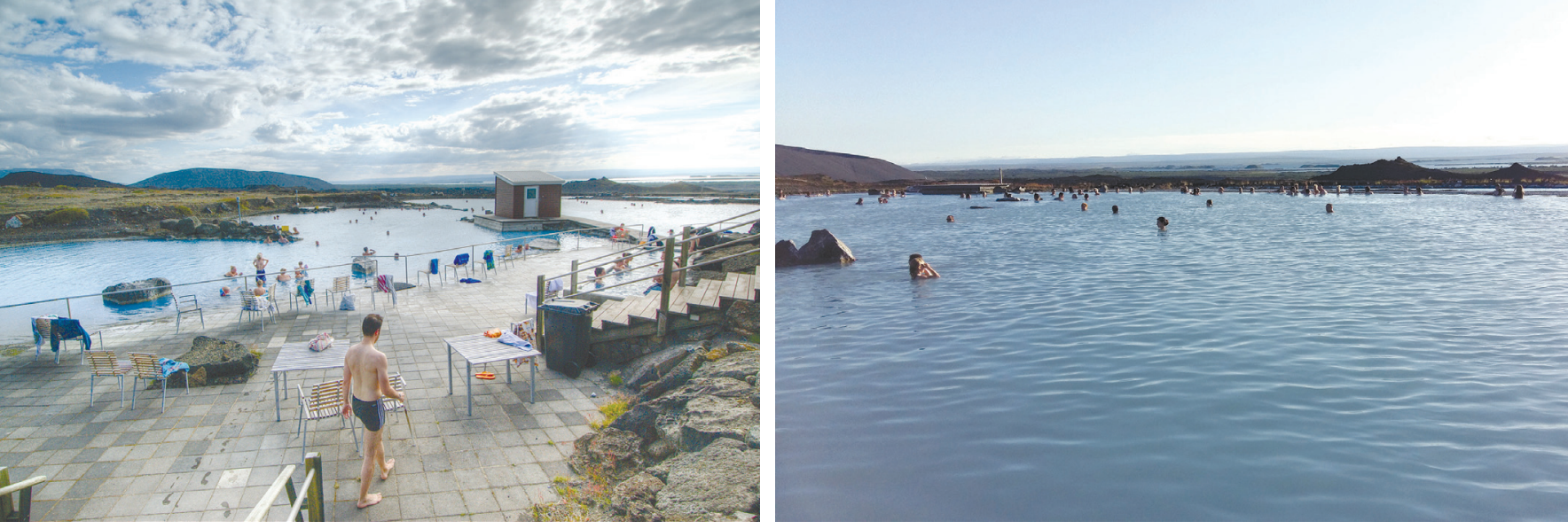

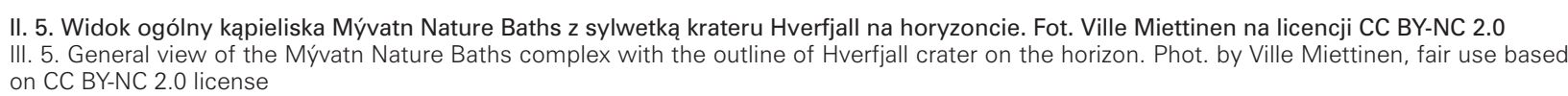

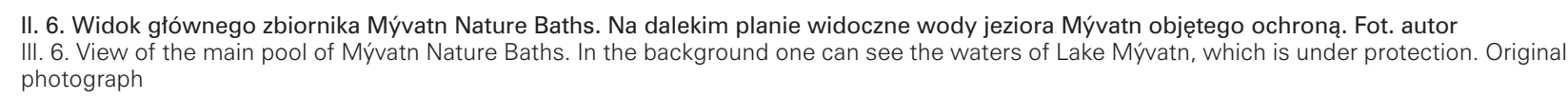

turalnej scenerii, służącymi przede wszystkim relaksowi. To, oraz wysoka opłata za wstęp odróżnia je od opisanych wczesniej basenów o charakterze sportowo-rekre acyjnym $^{20}$. Podobnie jak w przypadku Błękitnej Laguny założenie i funkcjonowanie Mývatn Nature Baths są ściśle związane $z$ działającą $w$ pobliżu elektrownią geotermalną. W obu przypadkach gorąca woda z odwiertów zasilających elektrownie, po oddaniu w turbinach części energii cieplnej jest kierowana do wymiennika ciepła podgrzewającego wodę $w$ kạpielisku.

Autorem projektu Mývatn Nature Baths jest islandzki architekt Halldór Gíslason ${ }^{21}$, który zaangażowany by w proces inwestycyjny od bardzo wczesnej fazy planowania. Z uwagi na położenie w obszarze o wyjatkowych walorach przyrodniczych i krajobrazowych oraz dążenie do zminimalizowania oddziaływania nowej inwestycji na otoczenie, proces projektowy trwał aż 10 lat i obejmował długotrwałe uzgodnienia dotyczące zarówno wyboru lokalizacii jak również sam projekt. Zielone światto dla in dla inwestycji przyniosla propozycja projektanta, by kapielisko usytuowac na obszarze dawnego żwirowiska,
a więc $w$ terenie już wcześniej przekształconym przez a więc W
człowieka.

Program użytkowy jest rozbudowany w porównaniu do wcześniej opisanych obiektów i obejmuje w strefie ogólwezesniej opisanych obiektow iobejmuje w strefie ogónodostejne sam wode oraz sklep z pamiątkami i przyborami toaletowym i duzy hol wejsciowy, a w częsci biletowanej rozbudowane szatnie, sanitariaty, sauny mokre, płytką, podłużna nieckę z gorącą wodą oraz rozlegly zbiornik wodny o powierzchni $5000 \mathrm{~m} 2$ i pojemności 3,5 mln litrów wody. W celu wpisania tak bogatej funkcji $w$ cenny krajobraz o dominujących liniach poziomych, program użytkowy został rozdystrybuowany w kilku małych, jedno- i dwukondygnacyjnych budynkach szalowanych drewnem i przekrytych dachami pulpitowymi. Swobodne uformowanie uwzględniało od początku mozliwość rozbudowy obiektu w przyszłości. Pospolita forma architektoniczn zgrupowania budynków inspirowana zabudowaniam mieszkalnymi i gospodarczymi oraz wykorzystanie pro- ily for relaxation. This, as well as the high entrance fee, is what makes them different from the previously described pools that feature a sports and recreation related character ${ }^{20}$. Similarly as in the case of the Blue Lagoon, the establishing and functioning of Mývatn geothermal power plant. In both cases the hot water from geothermal shafts that power the plant, after releasing some of its thermal energy in the plant's the water in the bathing facilit. up the water in the bathing facility.

The author of the design of Mývatn Nature Baths is the Icelandic architect Halldor Gíslason ${ }^{21}$, who was involved in the development process from the very carly stages of scape qualities and the pursuit of minimising the impect of the new project on the surroundings, the design procis design procoss lasted site and the design itself. The project was gre the thanks to the designer's proposal to have the bathin facility located on the site of a former gravel patha brownfield site that had already been transformed by man.

The functional programme is robust in comparison to the previously described facilities and covers a selfservice restaurant with a view of the water, a souvenir and toiletries store, as well as a large entrance hall in the public area, while in the ticketed area there are large changing facilities, toilets, wet saunas, a shallow, long pool with hot water and an expansive water pool with a surface area of $5000 \mathrm{~m} 2$ and a capacity of 3,5 million litres. In order to blend such a rich programme into the precious landscape with domino horizontal lines, it had to be distributed among sevof expanding the facility in the future from the very was inspired by residential and farm buildings, while Nature Baths is striclly associated with the nearby eral small, single or two-storey buildings covered in boards and featuring mono-pitched roofs. The freeform formation took into consideration the possibility start. The common architectural form of the complex stych technik budowlanych są sięgnięciem do tradycji budownictwa w Islandii jak i odpowiedzią na niewielk budżet na realizację inwestycji. Sam projektant określ jezzk architektury obiektu jako wernakularna architektura Islandii'22.

Podobnie jak we wcześniej opisanych przykładach, otwarcie na otaczający krajobraz jest wiodacym motywem projektowym Mývatn Nature Baths. W tym przypadk kontekstem przestrzennym sa surowe, rozlegte pola wowe pozbawione niemal wszelkiej roślinnóci, dala lalustro jeziora i sylwetka krateru Hverfjall na horyzoncie. Zgrupowanie budynków mieszczacych wejście i prze-

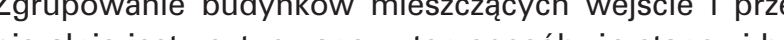

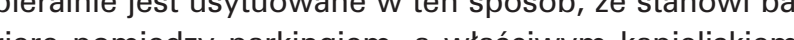
Dere pomiędzy pákingiem, a waściwy m kapieliskiem. Dopiero po wejsciu do budy a u, przejsciu przez szatnie isani kapieliska oczom odwiedzających ukazuje sie polożony nieco nizej zbiornik kąpielowy z wodą o mlecznej, blac obłękitnej barwie, kontrastującej z ciemnoszarym krajobrazem wulkanicznym, a w dalszym planie samo jezior Mývatn.

Obok gtównego zbiornika znajduje się betonowa po dłużna niecka z cieplejszą wodą do wygrzewania się. Jest ona zorientowana tak, by korzystający z niej miel widok w kierunku krateru Hverfjall. Program funkcjonalny obiektu nie obejmuje po stronie kąpieliska baru z napojami, ale możliwe jest wnoszenie napojów kupionych w restauracji.

Dyskusja

Kapielisko Mývatn Nature Baths ma charakter odmienny od dwóch poprzednio omówionych. Jego program nie obejmuje basenu pływackiego, jest natomiast wzbogacony o elementy służace relaksowi, takie jak sauny oraz duże, naturalnie zaaranżowane zbiornik $z$ wyprofilowanyi brzegami umożliwiajacymi sijo nie. Z powodu odmiennego charakteru obiektu i jego sławy, jak również ze wzgledu na wysoka cene biletu wstepu, duża czéśc odwiedzajacy stanowia biletu wodect

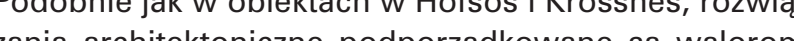
zrajo przez człowieka.

\section{Podsumowanie i wniosk}

Nawiązując do przywołanej na wsteppie definicji miasta Richarda Sennetta można stwierdzić, że baseny sa charakterystycznym dla Islandii rodzajem przestrze publicznej. Spotykają się w niej zarówno stali bywalc (mieszkańcy) w trakcie swoich regularnych aktywnośc jak i „obcy", w tym coraz liczniej odwiedzający wyspe turyści.

a sprawą programu użytkowego kąpielisk, który w większości przypadków obejmuje zarówno większy basen do pływania, jak i rozznej wielkosci, ksztaltow i rozmaicie zorientowane mniejsze, kilku- lub kilkunastoosobowe niecki lub jacuzzi z gorącą wodą, użytkownicy mają do the use of simple construction techniques was a refdition to being the answer to the small budget of the project. The designer himself described the language of the complex's architecture as Iceland's vernacular architecture 22 .

Similarly as in the case of the previously described cases, the opening towards the surrounding landscape is the leading design motif of Mývatn Nature Baths. In this case, the spatial context is formed by the austere, expansive lava fields devoid of practically any plant life, the faraway surface of the lake and the outline of Hverfjall crater on the horizon. The group of buildings that house the entrance and the changing rooms is laid out in such a manner as bathing facility proper. Only after entering the buildber and exiting outside on the side of the bathing facility one can see the bathing pool below with its milky, pale blue colour, which contrasts with the dark milky volcanic landscape and lake Mývatn itself, located on a further plane.

Apart from the main pool there is also an elongated concrete hot tub for warming oneself in. It is orientated so that its users have a view in the direction of Hverfjall crater. The functional programme of the facility does not cover a drink bar on the side of the pools, but it is possible to bring in drinks bought at the restaurant.

Discussion

The Mývatn Nature Baths complex has a differen character from the two that were previously discussed. Its programme does not cover a swimming pool, however, it is enriched by elements that are used for relaxation, such as saunas and large, naturally arranged pools with specially shaped edges for sitting on. Due to the different character of the faciity and its fame, as well as due to the high entry fee, tourists constitute a large part of its visitors. Similarly to the facilities in Hofsós and Krossnes, the architectural solutions are subjected to the qualities of the austere landscape, which has been only slightly altered by man.

\section{Summary and conclusions}

政

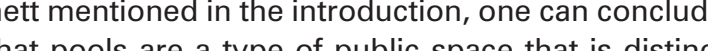
of Iceland. Regular visitors (resilents) met there during their regular activities, as well as "strangers", including increasingly large numbers of tourists visiting the island.

Due to the functional programme of the bathing facilities, which in most cases features both a larger swimming pool and Jacuzzi or hot tubs for several or around a dozen people, the users are dealing with the array of categories of distances defined by Edward T. Hall - from public distance, through social distance to private distance. These circumstances provide cond- 
czynienia z wachlarzem zdefiniowanych przez Edwarda T. Halla kategorii odleglości - od odlegiości publicznej, przez odległośc społeczna po odległośc osobista. Te okoliczności stwarzają warunki do zachodzenia charakterystycznych dla przestrzeni publicznych form komunikacji, takich jak kontakt wzrokowy, zdawkowe powitania czy rozmowy na tematy ogólne. Czynią one z basenów, w sensie przenośnym, teatr miejskiego życia, w którym użytkownicy są jednocześnie widzami i aktorami.

Wbrew temu co można by przypuszczać, program towarzyszacy (taki jak np kawiarnia) nie jest powszechnym rzupetnieniem podstawowej funk ji obiektów. Istotne pod katem spotecznego wymiaru architektury kapielisk, pazwiazania projektowe niecki lub jacuzzi z goraca woda: jej wilkość, ksztatt, orientacja wzgledem pozo-

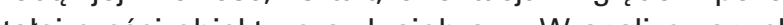
prypadkach stanowi on ważny element koncepcji projektowej.

PRZYPIS

M. Motak, Zarys urbanistyki i architektury Reykiavku, Czasopismo TechOd czasów zasiedlenia zaobserwowano dziatalność osiemnastu spostrod ponad stu wulkanów na wyspie.
${ }_{3}^{3}$ Grunty orne stanowia obecnie zaledwie $1 \%$ terytorium wyspy

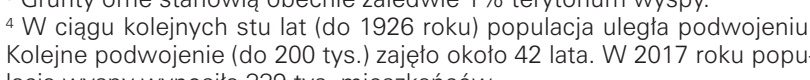
wycięty w średniowieczu z przeznaczeEn na budulec statków i budynków oraz na opat. eds. H. Bardadottir, L.K. Sturludottirl, National Energy Authority and Min am/handle/10802/6403/Energy_in_Iceland_2ed_2006.pdf?sequence =1.

odczyt 14.08.2018.
8 Geothermal Development and Research in Iceland, ed. S. Biörnsson
Orkustofnun, Reykiavik 2010, https://nea.is/media/utgafa/GD_loka.pdt. P. 14, odczyt 17.07.2018.

termalne, docierajac do zdecydowanej więk-

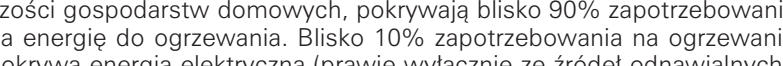
a poniziej $1 \%$ przypada na olej opatowy.
a pozostatych basenach woda jest

(a) O. D. Jónsson, O. Rastrick, Enjoying the outdoor pool in a cold climate W: Geothermal Energy (2017)
0060-5, odczyt 12.07.2018, p. 11

12 ibidem, p. 8.
${ }^{13}$ ibidem, p. 11.

C. Bain, A. Averbuck, Iceland, Lonely Planet Publications Pty Ltd, 2015

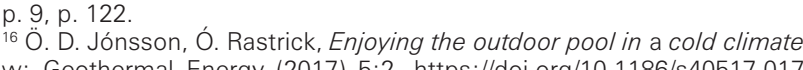

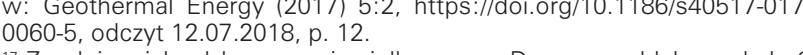

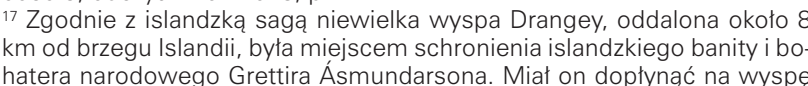
Wplaw.
${ }_{8}$ Przy powierzchni wynoszacej $707 \mathrm{~km}^{2}$, tj. ponad dwukrotnie więcej niz 'W 2016 roku kapielisko Mivvatn Nature Baths odwiedzito ponad 200 tys.

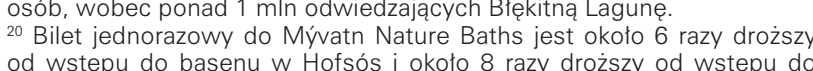
od wstępu do basenu w Hofsós i okoto 8 razy drozszzy od wstępu do Krossnesslaug.
${ }^{21}$ Halldor Gislason (zm. 2013) - architekti projektant, byly dziekan Wydziafu Wzornictwa i Architektury Islandzkiej Akademii Sztuk w Rejkiawiku oraz byly dziekan Wydziatu Wzornictwa Norweskiej Akademii Sztuk w Oslo.
22 K. E. Nelson, Arctic Beauty, Metropolis, December 2004, p. 105-111, https://kathsvilledotcom. files. Worddress.com/2015/11/metropolis_artichttps://kathsvilledotcom.files. Wordpress.com/201
-beauty_dec2004.pdf dostęp online 18.09.2018 tions for the occurrence of forms of communication case the purs or alical theatre of urban life, in which the users are simultaneously the audience and the actors.

Despite what can be assumed, an accompanying programme (such as, for instance, a coffee shop) is not a common supplementation of the basic functio of the facilities. Of essence, concerning the social dimension of the architecture of bathing facilities, are the design solutions of pools, Jacuzzi and hot-water chas. their size, shape, orientation relative to the recases that were andysed, they constitue an the ant element of the conceptual design.

\section{ENDNOTES}

1 M. Motak, An outline of the urbanism and architecture of Reykjia 2 Ever since the island has been settled eighteen from amongst
over a hundred of its volcanoes have been observed to be active. ${ }^{3}$ Farmland currently constitutes only $1 \%$ of the island's surface.
${ }^{4}$ Over the next one hundred years (up to 1926 ) the population of the island doubled. Another doubling (up to 200 thousand) took
around 42 years. In 2017 the island's population reached 339 tho-

https://Mww.ferdamalastofa.is/en/recearch-and-statistics/num-

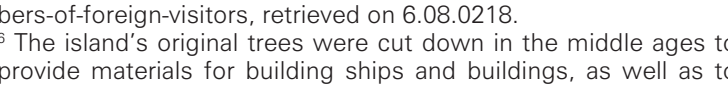
provide fuel.
7 Energy in I celand. Historical Perspective, Present Status, Future Energy in Iceland. Historical Perspective, Present Status, Future
Outlook, eds. H. Bardadottir, L.K. Sturludottir), National Energy
Authority and Ministries of Industry and Commerce, 2006, Authority and Ministries of Industry and Commerce, 2006, p.
10, https://rafhladan.is/bitstream/handle/10802/6403/Energy in

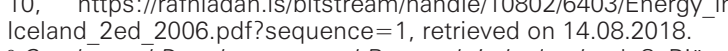
8 Geothermal Development and Research in Iceland, ed. S. Bijorns-
son, Orkustofnun, Reykiavik 2010, https://nea.is/medialutgafal GD'Ioka.pdf, p. 14, retrieved on 17.07.2018. On the scale of the country, geothermal sorings, by reaching the heating energy. Electric power (almost solely the demand for sources) covers close to $10 \%$, while less than $1 \%$ of heating is powered by oil.

water is heated thanks to electric powe

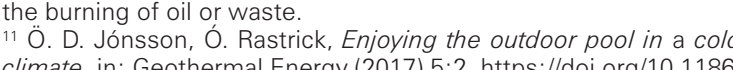
Climate, in: Geothermal Energy (2017) 5:2, httpps:///doi.org/10.1186
s40517-017-0060-5, retrieved on 12.07.2018, p. 11

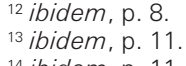

"C. Bain, A. Averbuck, Iceland, Lonely Planet Publications Pty Lto. 2015, p. 9. p. 122 .
${ }_{16}$ O. D. Jónsson, O. Rastrick, Enjoying the outdoor pool in a cold

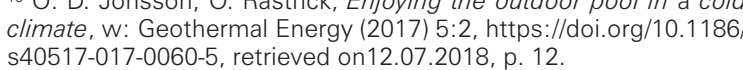

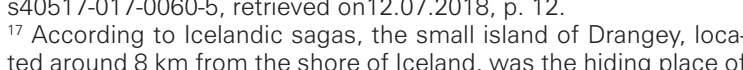
17 According to Icelandic sagas, the small island of Drangey, loca-
ted around $8 \mathrm{~km}$ from the shore of Iceland was the hiding place o
the Icelandic exile and national hero Grettir Asmundarson. He was the lcelandic exile and national hero Grettir Asmundarson. He was
said to have reached the is sland by bswimming to it.
18 W of Krakow.
19 In 2016 the Mívatn Nature Baths facility was visited by over 200
thousand people, compared to over 1 million visitors to the Blue Lagoon.
${ }^{20} \mathrm{~A}$ single-entry ticket to the complex is around six times as expen-
sive as the ticket to the Hofsós swimming pool and around 8 times

as expensive as the one to Krossneslaug.
2 12 Halldór Gíslasono (d. 2013) - architect and designer, former dean of the Arts in Reykjavik and the former dean of the Faculty of De-
of ${ }_{22} \mathrm{~K}$. E. Nelson. Arctic Beauty. Metropolis, Decs.

mer 2004, p. 105 polis_artic-beauty_dec2004.pdf retrieved on 18.09.2018
LITERATURA

[1] Energy in Iceland. Historical Perspective, Present Status, Future ity and Ministries of Industry and Commerce, 2006 .
[2] Gehl J., Zycie między budynkami, Wydawnictwo RAM, Kraków

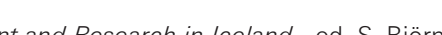
son, Orkustofnun, Reykiavik.

[4] Gislason H., Project: Mívatn Nature Baths, Iceland, Cumulus Working Papers, ed. E. Salmi, J. Lantto, Publication
sity of Art and Design, Helsinki 2004, p. $53-58$.

Jusson O. D., Rastrick D., Enjoying the outdoor pool in a cold and the socialization of everyday practices in Iceland, Geothermal En ergy (2017) 5:2, DOI 10.1186/s40517-017-0060-5 (7) Reykiaviku, Czasopismo Iechniczne, 3-A/2011, zeszyt 12, rok 108, s. $101-132$.
[7] Nelson K. E., Arctic Beauty, Metropolis, December 2004, p. $105-$

http://archdaily.com (odczyt 16.07.2018)

hitt: //dorigisislason net (odczyt 20.09 2018)

https://www.ferdamalastofa.is/en/recearch-and-statistics/numbers-of-toreign-visitors (odczyt 6.08. 0218

https://kathsvilledotcom.files. wordpress.com/2015/11/metropolis artic-beauty_dec2004.pdf (odczyt 18.09.2018)
https: //Www.myvatnnaturebaths.is//(odczyt 17.09.2018) hitts: / / nea is lodczyt 17.07 2018)

https:///rafhladan. is/bitstream/handle/10802/6403/Energy_in

\section{BIBLIOGRAPHY}

(1) Energy in Iceland. Historical Perspective, Present Status, Future thority and Ministries of Industry and Commerce, 2006.
[2] Gehl J., Zycie między budynkami, Wydawnictwo RAM, Krakó 2009 son, Orkustornun, Reykiavik.
[4] Gislason H. Project. Mivatn Nature Baths, Iceland, Cumulus Working Papers, ed. E. Salmi, J. Lantto, Publication
University of Aft and Design, Helsinki 2004, p. 53-58

[5] Jonsson O. D., Rastrick Ó., Enjoying the outdoor pool in a cold and the socialization of everyday practices in Iceland, Geotherma Energy (2017) 5.2, DOI 10.1186/s40517-017-0060-5.

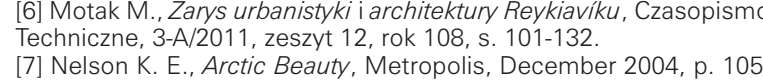

http://archdaily.com (odczyt 16.07.2018)

hitt: //basal. Is codczyt 23.08.2018)

https://www.ferdamalastofa. is/en/recearch-and-statistics/numbers-off-foreign-visitors (odczyt 6.08.0218)
https://flickr.com (odczyt 23.09.2018)

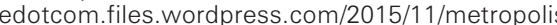

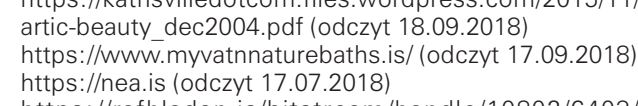
https:///rafhladan.is/bitstream/handle/10802/6403/Energy_in_
Iceland 2ed 2006. pdf?sequence $=1$ (odczyt 14.08.2018) 